\title{
The Level of Sense of Place in Inpres Market
}

\author{
Bambang Karsono*, Khana Rekha Putri, Sisca Olivia, Hendra A \\ Department of Architecture Engineering, Faculty of Engineering, Universitas Malikussaleh, Aceh, Indonesia \\ *Corresponding author E-mail: bambangkarsono@ unimal.ac.id
}

\begin{abstract}
Manuscript received 30 Nov 2021; revised 3 Dec 2021; accepted 10 Jan 2022. Date of publication 10 April 2022

Physical intervention in a market area tends to change user habits in responding to the space. This situation can ruin the authenticity of the sense of place and the loss of local identity for generations. This study aims to reveal the authenticity and understanding of the Inpres Market, a traditional market in Lhokseumawe. Re-development has been carried out at the Inpres Market to improve the layout of the stalls, change the architectural form of the building with a contemporary image, and increase the floor of the building vertically into two levels. Apprehensively this physical intervention will erode the meaning of place that has been attached to people's memories for a long time. This study must be conducted before any other new physical intervention occurs for any renovation or revitalization reason. This study is place-based research by choosing Inpres Market in Lhokseumawe as the case study. The research variable uses physical (tangible) and social (intangible) variables to reveal the sense of place in the market. The data was obtained using quantitative and qualitative methods, while the analysis was carried out in an exploratory, descriptive manner. The data collection method was conducted in two stages: observation, interviews, and questionnaires. The second stage of data collection involved 134 respondents, and a random sampling method was implemented to determine the respondents. The results showed that physical and social variables' influence in creating a sense of place is revealed.
\end{abstract}

Keywords: A Sense of Place, Place Attachment, Tangible Value, An Intangible Value.

\section{Introduction}

Sense of place is a topic that has been discussed extensively by researchers and remains interesting until today. Sense of business is a feeling that arises when someone is in a place to recognize the differences from each site [1]. The structure of a home can be formed from natural environment or artificial environment phenomena [1], [2]. The existence of a sense of place is an essential element in maintaining the identity of a business so that it can continue to be preserved [3] [4].

Maintaining the existence of a building together with its social life and historical value is a big challenge, especially in the era of globalization and digitalization. This effort is to maintain the local uniqueness and existence to prevent the loss of social and physical value due to the changes. A traditional market is an important object that needs to be maintained ned with a specific character for the local people. In Indonesia, every traditional market is believed to have its physical uniqueness and social nature, which are generated from the daily activities of local people into a distinctive identity and sense of place for the place [5].

One of the markets that maintain its sense of place is the Ubud Market in Bali, Indonesia. The Ubud Market's sense of place is still very well held [6]. This statement is based on their research findings that physical and social value as forming factors to the sense of place of the market are still well-maintained and sustainable. Biological factors include the architecture of the building, market space, characteristics of the merchandise, the focal point, and the way to sell products by using mobile cars. Meanwhile, social factors include users' understanding of the history of the place, cultural symbols, the character of traders and visitors, and trading transaction activities. The existence of a close attachment between place and humans through traditions and culture makes this market interesting for visitors due to its uniqueness. Lhokseumawe, a city in Indonesia, has specific uniqueness in the local market due to its strategic location, tradition, and culture. This city becomes a vital economic and trading distribution linkage between Medan, the capital city of North Sumatera Province, and Banda Aceh, the capital city of Aceh Province. One of the most active trading centers in Lhokseumawe is the Inpres Market; this traditional market is located downtown and has various commercial activities, public services, and settlements [7].

The Inpres consists of 2 (two) market areas: Pujasera Market and Old Market. Re-development efforts have been carried out within the Pujasera Market area to re-organize the market space for cloth shops. The new Pujasera Market consists of 2 stories contemporary building. The new layout tends to disrupt local people's habits in buying and selling activities. Initial observations show that the shops on the upper floors have fewer visitors due to local people who are reluctant to climb up the stairs. Nevertheless, this situation will hurt the sustainability of activities in the market and the gradual erosion of the region's sense of place [8].

This study intends to reveal the sense of place in the Inpres Market Lhokseumawe, to understand the specific character and uniqueness that only exists in that place. The research tries to tell the authenticity of the sense of place by using tangible physical variables and 
intangible social variables. The results of this research are expected to be used as a reference for physical and social interventions for any purposes of renovation or revitalization of the market [9] [10] [11].

\section{Literature Review}

Sense of place is an essential component that can change and upgrade space to become a place. A place is a spatial space with meaning and value for society or individuals [12]. Although primitive people mostly did their daily activities in the open land, they still needed to protect themselves from the wild animals and the extreme climate; therefore, they chose a cave as a safe place. So it can be said that humans live in a space and dwell in a place [9] [13]. The concept of place has a more tangible physical orientation than a space. Every place has a structure that consists of several essential elements [2].

When the word 'sense' is met with the word 'place,' it has a more precise meaning because sense has a clear and complete object with place attributes (social environment and physical environment). The purpose of the place is a unique personal experience of a particular place environment that influences the subjective assessment of that place [2]. Backgrounds can include cultural activities or events from the past that change the space into a specific character that the people consider and recognize. Hashemnezhad [14] suggests that the sense of place begins with the sensation received by people from an environment which then formulates a subjectively meaningful perception of the place [13] [9].

Sense of place is related to a personal subjective perception of the surrounding environment and emotional feelings towards a home; therefore, a sense of place consists of three components: cognition, perception, and physical character. Cognition, in this case, is the meaning of personal perception of the site. Jorgensen \& Stedman [15] argue that three dimensions need to be considered to create a place, i.e., personal feelings towards a place as an emotional dimension, personal belief in a place as a cognitive dimension, and the function of a place as a behavioral dimension [16]. Therefore, a home can be developed by creating the elements of form, process, and meaning that will generate the people's cognition, behavioral and emotional dimensions. People's perception of the place influences physical characteristics.) The physical parameters that affect the sense of place are size, scale, texture, color, smell, decoration, components, diversity, noise, and temperature [14]. Whereas identity, history, security, comfort, vitality, and memories influence how a person perceives a place he visits [17].

Table 1. Level of sense of place according to Shamai [18]

\begin{tabular}{cl}
\hline Level & \multicolumn{1}{c}{ Sense of place } \\
\hline$[0]$ & Not having any sense of place, people unable to understand the importance of the site. \\
\hline$[1]$ & $\begin{array}{l}\text { Knowledge of being located in a place is where a person knows a business and can identify the sym- } \\
\text { bols that exist but cannot feel an emotional attachment. }\end{array}$ \\
\hline$[2]$ & $\begin{array}{l}\text { Belonging to a place, the people feel familiar and understand an emotional attachment to the site and } \\
\text { can distinguish existing symbols and appreciate them. }\end{array}$ \\
\hline$[3]$ & $\begin{array}{l}\text { Attachment to a place is the level where the people have an emotional attachment with a home with a } \\
\text { unique identity and character that can be seen through existing symbols. }\end{array}$ \\
\hline$[4]$ & $\begin{array}{l}\text { Identifying with the place goals, which not only individual but a group of people who visit the place } \\
\text { already know the purpose of the site, the area provides satisfaction and suitable for them. }\end{array}$ \\
\hline$[5]$ & $\begin{array}{l}\text { Involvement in a place, in this stage, in the form of real action from people in that place, will take } \\
\text { classes, such as being willing to donate time, energy, and money for the sake of the site. }\end{array}$ \\
\hline$[6]$ & $\begin{array}{l}\text { Sacrifice for a place is the highest level of sense of place where a people feel a deep commitment to a } \\
\text { site, which makes a person willing to sacrifice for the attributes and values that exist in that place. }\end{array}$ \\
\hline
\end{tabular}

Punter and Montgomery argued that three components of the sense of place need to be considered, i.e., activity, physical form, and the meaning of the place, that can develop the identity of a place [19]. Each place has a different level of sense of place. People can be involved in a social activity if they have a solid emotional attachment to the visited place [17]. A place with a high level of sense of place will affect people to feel at home or want to stay longer and interact with other people in that place [18]. According to Shamai [18], there are seven levels of sense of place, as shown in Table 1 [20] [6] [15].

\section{Methods}

The study implements the place-based approach, where the Inpres Market in Lhokseumawe is chosen as the research object. The research intends to reveal the physical (tangible) and social (intangible) variables that are believed contribute important influences to establishing a sense of place. The data were obtained using quantitative and qualitative methods, while the analysis was carried out in an exploratory, descriptive technique. Data collection was carried out in two stages; the first stage used observation and interview techniques to obtain and determine elements or physical elements and activities to be examined further in the second stage quantitative data collection process. Observation focuses on determining the characteristics of domination, identity, comfort, security, durability, memories, cultural associations, impressions, satisfaction, community participation, main activities, supporting activities, landmarks, and paths according to predetermined variables. The second data collection stage uses a questionnaire survey technique involving 134 respondents. A random sampling method was implemented to determine the respondents.

\section{Results and Discussion}

The object of this research is the Inpres Market, located on Listrik Street, Tumpok Teungoh Village, Banda Sakti District, Lhokseumawe City, Aceh Province, Indonesia (Figure 1). The research was conducted to reveal the sense of place in the Inpres Market area and the several factors influencing it. Data collection was carried out in two stages. The data obtained in the first stage through qualitative observation will be further tested in the second stage quantitatively using a questionnaire. Observations are conducted to accept and determine elements or physical elements. Activities focus on determining the characteristics of domination, identity, comfort, security, engagement, 
memories, cultural associations, impressions, satisfaction, community participation, main activities, supporting activities, landmarks, and paths as research variables.
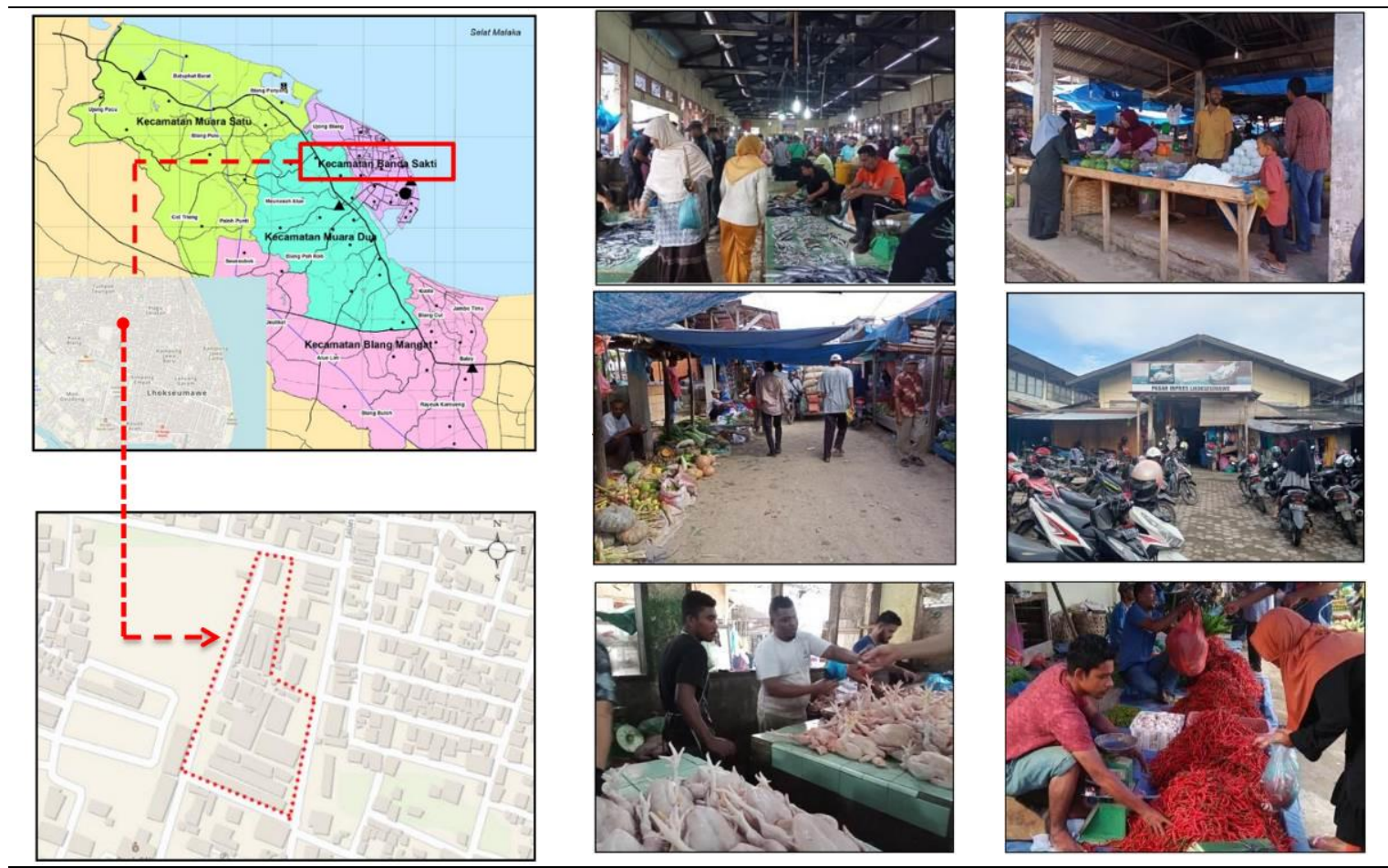

Fig 1. The Inpres market location map and its general atmosphere.

Interviews were conducted to cross-check the results of observations made and obtain in-depth perception data; interviews were conducted in-depth (in-depth interviews). The selected informants have been involved in social life for a relatively long time at the research location. Results from observations and interviews showing the places that will be tested in the second stage of data collection using a questionnaire survey technique as follows: vegetable stalls, groceries kiosk, fish/meat stalls, wholesale shops, market corridor, parking area, and direct access to the market.

The survey was conducted on 134 respondents by categorizing the questions into two variables, namely tangible and intangible. Table 2 shows the actual variables and questions addressed in the questionnaire, whereas Table 3 describe the intangible variables and statement addressed. The feedback from intangible variables will be in 4 levels Likert scale format.

Table 2. Tangible variables

\begin{tabular}{|c|c|c|c|}
\hline & Tangible variables & Question addressed & Selected object/space \\
\hline 1 & Domination & Which object/space is dominate & \multirow{6}{*}{$\begin{array}{ll}\text { - } & \text { Vegetable stalls } \\
\text { - } & \text { Groceries kiosk } \\
\text { - } & \text { Fish/meat stalls } \\
\text { - } & \text { Wholesale shops } \\
\text { - } & \text { Market corridor } \\
\text { - } & \text { Parking area } \\
\text { - } & \text { Main access }\end{array}$} \\
\hline 2 & Identity & Which object is apparent as an identity & \\
\hline 3. & Main activity & Which space is played as the main activity & \\
\hline 4. & Secondary activity & $\begin{array}{l}\text { Which space is played as a secondary activ- } \\
\text { ity }\end{array}$ & \\
\hline 5. & Landmark & Which object is transparent as a landmark & \\
\hline 6. & Path & Which space is clear as a pathway & \\
\hline
\end{tabular}

Table 3. Intangible variables

\begin{tabular}{|c|c|c|c|}
\hline & Intangible variables & Statement addressed & Selected object/space \\
\hline 1 & Memory & I have a memory of this object/space & \multirow{8}{*}{$\begin{array}{ll}\text { - } & \text { Vegetable stalls } \\
\text { - } & \text { Groceries kiosk } \\
\text { - } & \text { Fish/meat stalls } \\
\text { - } & \text { Wholesale shops } \\
\text { - } & \text { Market corridor } \\
\text { - } & \text { Parking area } \\
\text { - } & \text { Main access }\end{array}$} \\
\hline 2 & Length of engagement & I spent a long time to this object/space & \\
\hline 3. & Satisfaction & I satisfy with this object/space & \\
\hline 4. & Community participation & I involve in making good of this object/space & \\
\hline 5. & Cultural associations & I involve in any cultural activity here & \\
\hline 6. & Impression & I feel the object/space has a good impression & \\
\hline 7. & Comfort & I feel the object/space is comfort & \\
\hline 8. & Security & This space is secure and safe & \\
\hline
\end{tabular}

The findings from each question regarding the level of sense of place within the study area can be seen in Table 4 and Table 5 . The data indicate that the purpose of business in the study area tends to be at the level of number four (4, identifying with the place goals, which not only individual but a group of people who visit the place already know the purpose of the site, the site provides satisfaction and suitable for them) and number five (5, involvement in an area, in this stage in the form of real action from people in that place will take 
place, such as being willing to donate time, energy and money for the sake of the site.) It indicates that respondents tend to be quite familiar with and know the characteristics of the Inpres Market, such as the location, function, and condition of the place. Some respondents did not seem interested in the area, but they felt togetherness and solidarity. They also realize that The Inpres Market has a vital role as a government facility in the city. On the other hand, primarily respondents cannot relate the history and characteristics of the place to their level of attachment to the site.

The findings indicate that the building's main activity and visual character affect the sense of place of the Inpres Market. The dominance of the vegetable stall's shape influences the respondent's identity-forming that provides an observed visible object given within the site. Respondents can immediately choose the vegetable stall as the most dominant because of the activities that they usually do. This is undoubtedly by Seamon \& Sower [1], which states that the quality of visual values in an area exists because of the physical quality formed by the relationship between visual elements in an environmental site that the respondents have recorded.

Refer back to Montgomery [21], which argues that a place has vitality or the main character that supports the emergence of all user activities in it. In the context of urban design, Montgomery stated that to create a sense of place; a place must have 3 (three) essential elements, namely form, activity, and image. In line with this opinion, the Inpres Market consists of 2 essential parts: the specific building and the activities in the building. The image element has been constructed from the social factors in the way the communities interact and form an attachment that contributes to increasing the sense of place.

The factors that develop the sense of place in the Inpres Instruction Market are obtained based on the respondents' assessments. Respondents argue that the Inpres Market in Lhokseumawe is a place for a trading center that has become the city's identity. The Inpres market functions as a place to find livelihoods for the surrounding community so that initiatives emerge to participate for the sake of market sustainability. This is one of the points that has resulted in a strong bond between the community and the market. Vegetables, fish/meat markets, and wholesale areas are considered the main activity places. The activities that occur dominate and also strengthen the identity of the market. The results of data analysis showed that $43 \%$ of respondents stated that the vegetable stall was the center of the main activity, followed by the fish/meat market with an assessment of $34 \%$ as the place with the second busiest activity. Based on the data obtained, the description of the sense of place in the Inpres Market area can be seen through the meaning of Inpres Market as a people's market by the surrounding community; this meaning can be seen through interaction and affection/feeling comfortable, safe and at home felt by users. The existence of social interactions in the form of admonishing each other, helping each other, and cooperation is the basis that creates a sense of place in the realm of social factors.

Table 4. Findings on tangible variables

\begin{tabular}{llccccccc}
\hline \multirow{2}{*}{} & \multirow{2}{*}{ Selected object/space } & \multicolumn{2}{l}{ Tangible variables $(\%)$} & & & & \\
\cline { 3 - 8 } & & Domination & Identity & Main Activity & Secondary Activity & $\begin{array}{c}\text { Land- } \\
\text { mark }\end{array}$ & \multirow{2}{*}{ Path } \\
\hline 1 & Vegetable stalls & 35.82 & 24.63 & 29.85 & 14.93 & 20.90 & 11.19 \\
\hline 2 & Groceries kiosk & 12.69 & 9.70 & 10.45 & 10.45 & 8.96 & 0.00 \\
\hline 3 & Fish/meat stalls & 26.12 & 22.39 & 26.12 & 22.39 & 27.61 & 5.97 \\
\hline 4 & Wholesale shops & 17.91 & 19.40 & 11.19 & 13.43 & 1.49 & 3.73 \\
\hline 5 & Market corridor & 5.22 & 20.90 & 12.69 & 10.45 & 6.72 & 28.36 \\
\hline 6 & Parking area & 2.24 & 0.00 & 5.97 & 25.37 & 34.33 & 18.66 \\
\hline 7 & Main access & & 0.00 & 2.99 & 3.73 & 2.99 & 0.00 & 32.09 \\
\hline & & Total & 100 & 100 & 100 & 100 & 100 & 100 \\
\hline
\end{tabular}

Table 5. Findings on intangible variables

\begin{tabular}{|c|c|c|c|c|c|c|c|c|c|}
\hline \multirow[b]{2}{*}{$\begin{array}{c}\text { Sense } \\
\text { of place } \\
\text { level }\end{array}$} & \multirow[b]{2}{*}{$\begin{array}{l}\text { Likert scale } \\
\text { analysis }\end{array}$} & \multicolumn{8}{|c|}{ Intangible variables (\%) } \\
\hline & & Memory & $\begin{array}{c}\text { Length of } \\
\text { Engage- } \\
\text { ment }\end{array}$ & $\begin{array}{l}\text { Satisfac- } \\
\text { tion }\end{array}$ & $\begin{array}{l}\text { Commu- } \\
\text { nity partic- } \\
\text { ipation }\end{array}$ & $\begin{array}{c}\text { Cultural } \\
\text { associa- } \\
\text { tions }\end{array}$ & $\begin{array}{l}\text { Impres- } \\
\text { sion }\end{array}$ & $\begin{array}{l}\text { Com- } \\
\text { fort }\end{array}$ & $\begin{array}{l}\text { Secu- } \\
\text { rity }\end{array}$ \\
\hline$[0],[1]$ & $\begin{array}{l}\text { Strongly dis- } \\
\text { agree }\end{array}$ & 10.45 & 29.85 & 14.18 & 14.18 & 5.97 & 6.72 & 11.94 & 20.15 \\
\hline [2], [3] & Disagree & 24.63 & 23.13 & 25.37 & 25.37 & 14.18 & 23.13 & 21.64 & 17.91 \\
\hline$[4],[5]$ & Agree & 37.31 & 40.30 & 14.18 & 14.18 & 32.09 & 29.85 & 38.06 & 39.55 \\
\hline \multirow[t]{2}{*}[6]{} & $\begin{array}{l}\text { Strongly } \\
\text { agree }\end{array}$ & 27.61 & 6.72 & 46.27 & 46.27 & 47.76 & 40.30 & 28.36 & 22.39 \\
\hline & Total & 100 & 100 & 100 & 100 & 100 & 100 & 100 & 100 \\
\hline
\end{tabular}

\section{Conclusion}

Physical settings, activities, and images contribute to the sensitivity of pace in the Inpres Market. The variables that have the most significant effect on the importance of place are domination, identity, activities, landmarks, and paths. The relationship that occurs from human activities to a site that is specifically considered, found, known, and remembered by the people involved are the elements to develop the sense of place. It is also reinforced by the survey results, where the dominance and identity variables are formed due to the influence of the user's activities and behavior on the Presidential Instruction market space, starting from remembering, interacting, organizing personal items to creating personal space with vague boundaries. Overall, concrete variables make an essential contribution to the sense of place in the Inpres Market area compared to intangible variables. Still, combining these two variables provides an assessment of its meaning to the importance of the site. 


\section{References}

[1] D. Seamon and J. Sowers, "Place and placelessness (1976): Edward Relph," Key Texts Hum. Geogr., pp. 43-52, 2008, DOI: 10.4135/9781446213742.n5.

[2] C. Norberg-Schulz, "Genius loci : towards a phenomenology of architecture," Acad. Ed. London, 1980.

[3] B. Karsono, S. Indira, and Deni, "The significance of uniqueness, comfort, security, and safety to place attachment," J. Teknol., vol. 78, no. 5, pp. 179-183, 2016, DOI: 10.11113/jt.v78.8278.

[4] I. G. Dharma Utamayasa, "Effect Physical Activity and Nutrition During The Covid-19 Pandemic," Int. J. Eng. Sci. Inf. Technol., vol. 1, no. 1, 2021, DOI: 10.52088/majesty.v1i1.58.

[5] D. Riyan Rizaldi, E. Nurhayati, Z. Fatimah, and Z. Amni, "The Importance of Parental Assistance in Supervising the Use of Technology for Children During the Home Learning Program," Int. J. Eng. Sci. Inf. Technol., vol. 1, no. 3, 2021, DOI: 10.52088/majesty.v1i3.78.

[6] M. Rahadiyanti, A. Kusumowidagdo, D. K. Wardhani, T. S. Kaihatu, and I. A. I. Swari, "Sense of Place Kawasan Wisata Pasar Ubud," Nat. Natl. Acad. J. Archit., vol. 6, no. 2, p. 123, 2019, doi: 10.24252/nature.v6i2a3.

[7] R. Mirsa, M. Muhammad, E. Saputra, and I. Farhana, "Space Pattern of Samudera Pasai Sultanate," Int. J. Eng. Sci. Inf. Technol., vol. 1, no. 2, 2021, doi: 10.52088/ijesty.v1i2.120.

[8] D. Kumar, "Power System Restoration Using Multilayer Perceptron," Int. J. Eng. Sci. Inf. Technol., vol. 1, no. 1, 2021, DOI: 10.52088/majesty.v1i1.35.

[9] D. Deni, B. Karsono, R. Mirsa, A. Safyan, and E. Saputra, "The Divergence Between Prophet's Masjid and Present Masjid: An Architectural Essay," Int. J. Eng. Sci. Inf. Technol., vol. 1, no. 2, pp. 130-134, 2021, DOI: 10.52088/majesty.v1i2.136.

[10] F. R. Scartoni et al., "Physical Exercise and Immune System in the Elderly: Implications and Importance in COVID-19 Pandemic Period," Front. Psychol., vol. 11, no. November 2020, DOI: 10.3389/fpsyg.2020.593903.

[11] C. Giles, "Youth Justice: Challenges to Practice," J. Soc. Work Pract., vol. 30, no. 1, 2016, DOI: 10.1080/02650533.2015.1035636.

[12] B. Karsono and J. Wahid, "Attributes and Characteristics of Place Attachment," in Applied Mechanics and Materials, 2015, vol. 747, pp. 132-135, DOI: 10.4028/www.scientific.net/amm.747.132.

[13] M. F. Firmansyah and H. Z. Maulana, "Empirical Study of E-Learning on Financial Literacy and Lifestyle : A Millenial Urban Generations Cased Study," Int. J. Eng. Sci. Inf. Technol., vol. 1, no. 3, pp. 75-81, 2021.

[14] H. Hashemnezhad, A. A. Heidari, and P. Mohammad Hoseini, "Sense of place" and "place attachment," Int. J. Archit. Urban Dev., vol. 3, no. 1, pp. 5-12, 2013.

[15] B. S. Jorgensen and R. C. Stedman, "Sense of place as an attitude: Lakeshore owners attitudes toward their properties," J. Environ. Psychol., vol. 21, no. 3, pp. 233-248, 2001.

[16] S. Syafwandi, D. Setyo Sembodo, A. Tua Munthe, and A. Sumarno, "Analysis of The Use of Sawdust Waste As Concrete Mixture Add Material Against Workability and Compressive Strength Concrete With Three Concrete Treatment Methods," Int. J. Eng. Sci. Inf. Technol., vol. 1, no. 2, 2021, DOI: 10.52088/majesty.v1i2.109.

[17] B. Karsono, Deni, and C. A. Fitri, "Assessment of functional and emotional attachment in Malacca Riverfront Promenade," J. Teknol., vol. 78, no. 5, pp. 153-157, 2016, DOI: 10.11113/jt.v78.8271.

[18] S. Shamai, "Sense of place: an empirical measurement," Geoforum, vol. 22, no. 3, pp. 347-358, 1991, DOI: 10.1016/00167185(91)90017-K.

[19] C. Dameria, R. Akbar, P. N. Indradjati, and D. S. Tjokropandojo, "Tinjauan Ulang Potensi Sense of place dalam Pelestarian Kawasan Pusaka Perkotaan,” Tataloka, vol. 22, no. 3, pp. 379-392, 2020, doi: 10.14710/tataloka.22.3.379-392.

[20] P. C. Stenning and C. D. Shearing, "Corporate justice: Some preliminary thoughts," Aust. N. Z. J. Criminol., 1984, DOI: $10.1177 / 000486588401700203$.

[21] J. Montgomery, "Making a city: urbanity, vitality, and urban design," J. Urban Des., vol. 3, no. 1, pp. 93-116, 1998, DOI: 10.1080/13574809808724418. 